\title{
Nilai Satya dan Pengendalian Internal Sebagai Strategi Meminimalkan Tindakan Fraud Pada LPD di Kabupaten Buleleng
}

\author{
Gede Widiadnyana Pasek ${ }^{1 *}$, Ni Luh De Erik Trisnawati ${ }^{2}$. \\ ${ }^{123}$ STIE Satya Dharma Singaraja, Indonesia \\ *Gede Widiadnyana Pasek: widiadnyanapasek@gmail.com ${ }^{1 *}$
}

\section{Abstract}

Penelitian ini bertujuan untuk menemukan bukti empiris mengenai pengaruh Nilai Satya, dan Pengendalian Internal terhadap kecenderungan kecurangan akuntansi pada Lembaga Perkreditan Desa Kabupaten Buleleng. Penelitian ini berlokasi Lembaga Perkreditan Desa (LPD) Kabupaten Buleleng. Penelitian ini menggunakan pendekatan kuantitatif. sampel penelitian yang digunakan ini adalah 266 responden. Pengujian hipotesis dalam penelitian ini menggunakan teknik analisis regresi berganda dengan pendekatan statistik yang dioperasikan melalui program SPSS. Hasil penelitian ini menunjukkan bahwa nilai Satya dan Pengendalian Internal, berpengaruh terhadap kecenderungan kecurangan akuntansi.

Keywords: Nilai Satya, Pengendalian Internal, Kecurangan Akuntansi

\section{Abstract}

This study aims to find empirical evidence regarding the effect of Satya Value, and Internal Control on the tendency of accounting fraud at the Village Credit Institution of Buleleng Regency. This research is located at the Village Credit Institution (LPD) of Buleleng Regency. This study uses a quantitative approach. The research sample used in this research is 266 respondents. Hypothesis testing in this study uses multiple regression analysis techniques with a statistical approach which is operated through the SPSS program. The results of this study indicate that the value of Satya and Internal Control has an effect on the tendency of accounting fraud.

Keywords: Satya Value, Internal Control, Accounting Fraud

\section{Introduction}

Lembaga Perkreditan Desa (LPD) merupakan lembaga keuangan di Bali yang memiliki keunikan tersendiri karena LPD merupakan lembaga keuangan yang bebasis desa adat dan budaya di Bali. Tujuan didirikan LPD adalah salah satunya memperkuat perekonomian desa adat di Bali, dengan kata lain semakin kuat LPD maka akan semakin berkembang perkonomian desa adat di Bali. Salah satu permasalahan yang terjadi pada LPD di Bali adalah tindakan kecurangan (fraud) akuntansi. Kasus fraud akuntansi yang terjadi di LPD di Bali menunjukkan bahwa masih kuranganya pengendalian di dalam manajeman di LPD. Tindakan-tindakan fraud yang terjadi, menimbulkan ketidakpercayaan masyarakat desa adat terhadap LPD, sehingga dengan timbulnya ketidakpercayaan masyarakat desa adat terhadap LPD maka konsistensi dari LPD akan semakin sulit dipertahankan dan akan sulit bagi desa adat di bali untuk mengembangkan perekonomiannya.
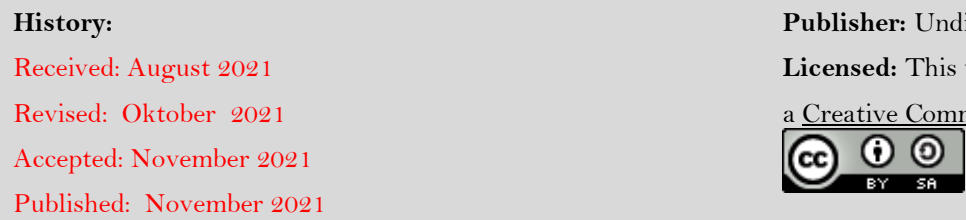
Berdasarkan data yang diperoleh melalui bulelengkab.go.id pada tahun 2020 Jumlah LPD yang ada di kabutapen Buleleng adalah 169 LPD sekitar 20\% LPD yang kategorinya kurang sehat, permasalahan ini muncul karena beberapa sebab, salah satunya terdapat tindakan fraud. Terdapat kasus tentang kecurangan (fraud) akuntansi, pada media online bali post (2018) memberitakan salah satu LPD di kecamatan Buleleng terjadi proses penggelapan uang nasabah selama bertahun-tahun, kemudian media online kompas (2020) memberitakan lagi kasus dugaan kredit fiktif di salah satu LPD di kecamatan Gerokgak, Ini mengindikasikan bahwa pengendalian manajeman di dalam LPD masih perlu diperbaiki. Faktor penyebab terjadinya fraud tidak terlepas dari keefektifan Pengendalian internal (Shintadevi, 2015). Pengendalian intern perusahaan yang semakin efektif akan mengakibatkan rendahnya kecurangan akuntansi (Artini, 2014). Selain itu, pengendalian internal juga memberikan jaminan yang wajar terhadap informasi bisnis yang akurat demi keberhasilan perusahaan. Oleh sebab itu, jika pengendalian internal yang telah dirancang dan dilaksanakan dengan efektif maka pengendalian internal dapat diandalkan untuk melindungi dari fraud termasuk apabila ada pegawai yang berniat melakukan tindakan fraud. Selain pengendalian internal yang efektif diperlukan juga nilai spiritual dari dalam diri karyawan untuk mengurangi kecurangan akuntansi (Pasek,dan Trisnawati 2019). Didalam ajaran hindu nilai spritual yang terkandung untuk menaati aturan ada didalam ajaran satya. Ajaran satya merupakan ajaran yang mengutamakan kesetiaan atau ketaatan, karena ketaatan itu ceminan dari kepribadian seseorang (Ariyoga,2019). Orang yang tidak memahami dan tidak melaksanakan ajaran satya, maka orang itu tidak bisa dipercaya. Ketaatan dalam Hindu merupakan sebuah ajaran agama yang wajib diamalkan. begitu juga penerapan dalam atuaran akuntansi. Aturan akuntansi memberikan pedoman bagi manajemen dalam melakukan kegiatan akuntansi dengan baik dan benar sehingga menghasilkan laporan keuangan yang efektif dan mampu menghasilkan informasi yang handal kepada pihak yang berkepentingan (Adelin dan Fauzihardani, 2013).

Penelitian ini memiliki tujuan khusus yaitu untuk mengetahui pengaruh nilai satya dan pengendalian internal untuk meminimalkan tindakan fraud Akuntansi pada LPD di Kabupaten Buleleng. Urgensi dari penelitian ini adalah karena dapat memberikan manfaat bagi manajamen LPD di kabupaten buleleng untuk dapat mengambil kebijakan untuk mengurangi tindakan fraud terutama dalam memperkuat nilai satya dalam melaksanakan aturan akuntansi dan pengendalian internal, sehingga dan hal tersebut dapat menjaga keajegan dari LPD di Bali khususnya di kabupaten buleleng.

\section{Methods}

\section{A. Rancangan Penelitian}

Penelitian ini bertujuan untuk menganalisa pengaruh antara varibel independen yaitu pengendalian internal, dan nilai satya dalam aturan akuntansi dengan variabel dependen yaitu kecurangan (fraud) akuntansi. Penelitian ini menggunakan pendekatan penelitian kuantitatif. Analisis yang digunakan dalam penelitian ini adalah analisis regresi berganda. Populasi dari penelitian ini adalah seluruh pegawai LPD kabupaten Buleleng. Sampel yang digunakan adalah pegawai LPD Kabupten Buleleng karena subyek penelitian merupakan praktisi dan subyek lebih memahami situasi dan kondisi di lapangan.

\section{B. Teknik Pengumpulan Data dan Analisis Data}

Peneliti menggunakan teknik pengumpulan data yaitu dengan meyebarkan kuesioner. Perhitungan bobot penilaian bagi responden dengan menggunakan skala 
likert yang mana merupakan metode yang mengukur sikap dengan menyatakan setuju dan tidak setuju terhadap subjek (Sugiyono, 2015). Pada penelitian ini, yang menjadi sampel penelitian ini adalah pegawai LPD dan dilakukan dengan penyebaran kuesioner mengenai pengaruh pengendalian internal, dan nilai satya terhadap kecurangan (fraud) akuntansi. Kuesioner dalam penelitian ini menggunakan pernyataan terstruktur yang alternatif jawabannya telah tersedia. Metode analisis data dalam penelitian ini adalah dengan menggunakan teknik analisis kuantitatif. Analisis kuantitatif dilakukan dengan cara menganalisis suatu permasalahan yang diwujudkan dengan kuantitatif. Alat analisis yang digunakan dalam penelitian ini adalah analisis regresi berganda. Untuk menjaga validitas dan reliabilitas butir-butir pertanyaan yang ada pada kuesioner dilakukan uji validitas dan reliabilitas terhadap kecenderungan kecurangan akuntansi, nilai satya dan Pengendalian internal.

\section{Lokasi Penelitian}

Penelitian ini dilakukan di seluruh LPD Kabupaten Buleleng dengan pertimbangan, Kabupaten Buleleng merupakan wilayah terluas dari kabupaten yang ada di Provinsi Bali, yang mempunyai jumlah LPD melebihi jumlah desa pakraman yang menaunginya. Jumlah LPD yang ada sebanyak 169 buah yang tersebar di sembilan kecamatan yaitu, kecamatan Banjar, Sukasada, Sawan, Kubutambahan, Tejakula, Seririt, Busungbiu, Gerogak, dan Buleleng, sedangkan jumlah desa pakraman yang ada di Kabupaten Buleleng sebanyak 149 desa pakraman.

\section{Definisi Opersional}

\section{Kecurangan (fraud) Akuntansi}

Kecenderungan Kecurangan Akuntansi adalah keinginan untuk melakukan segala sesuatu untuk memperoleh keuntungan dengan cara yang tidak jujur seperti menutupi kebenaran, penipuan, manipulasi, kelicikan atau mengelabui yang dapat berupa salah saji atas laporan keuangan, korupsi dan penyalahgunaan aset. Instrumen yang digunakan untuk mengukur Kecenderungan Kecurangan Akuntansi yang mengacu pada pada SPAP seksi 316 (2001) dan shintadevi (2015) yang dikembangkan dalam penelitian Udayani dan sari (2017).

\section{Pengendalian Internal}

Menurut Yusar dan Fitri (2013) pengendalian internal adalah sebuah proses, dipengaruhi oleh dewan entitas direksi, manajemen dan personil lainnya, yang di rancang untuk memberikan keyakinan memadai tentang pencapaian tujuan dalam kategori berikut: efektivitas dan efisiensi operasi, keandalan pelaporan keuangan, kepatuhan terhadap berlaku hukum dan peraturan dan pengamatan aset terhadap akuisisi yang tidak sah, penggunaan atau pelepasan.

\section{Nilai Satya}

Nilai satya adalah ajaran yang mengutamakan kesetiaan atau ketaatan, karena ketaatan itu ceminan dari kepribadian seseorang (Ariyoga, 2019) Nilai satya diukur melalui ketaatan aturan akuntansi. Aturan akuntansi dibuat sedemikian rupa sebagai dasar dalam penyusunan laporan keuangan. Dalam standar akuntansi terdapat aturan-aturan yang harus digunakan dalam pengukuran dan penyajian laporan keuangan yang berpedoman terhadap aturan-aturan yang dikeluarkan oleh IAI (Ikatan Akuntan Indonesia). Ketaatan aturan akuntansi merupakan suatu kewajiban bagi organisasi untuk mematuhi segala aturan 
akuntansi dalam melaksanakan penysunan laporan keuangan agar tercipta akuntabilitas dan transparansi pengelolaan keuangan dan laporan keuangan yang berkualiatas (Rizky dan Fauziah, 2017)

\section{Hasil dan Pembahasan}

Teknik pengumpulan data pada penelitian ini guna untuk memperoleh data penelitian adalah menyebarkan kuesioner secara langsung terhadap responden. Variabel yang diteliiti dalam penelitian ini adalah Konsep Satya, Pengendalian Internal, dan Kecurangan Akuntansi. Penelitian dilakukan dengam menguji instrument penelitian yaitu menguji validitas dan reliabilitas instrument penelitian, setelah itu data data dianalisis dengan menggunakan analasisis regersi berganda dan menguji hipotesis penelitian. Berikut hasil penelitian yang dilakukan di LPD Kabuptaen buleleng

\section{A. Uji Validitas dan Reliabilitas Instrumen Penelitian}

Pengujian validitas dan reliabilitas terhadap instrumen di dalam kuesioner sangatlah penting dilakukan untuk memperoleh hasil penelitian yang valid dan reliabel. Dengan demikian instrumen yang valid dan reliabel merupakan syarat mutlak untuk mendapatkan hasil penelitian yang valid dan reliabel.

Instrumen dikatakan valid apabila mampu mengukur apa yang diinginkan, dan dapat mengungkapkan data dari variabel yang diteliti secara tepat, validitas menunjukkan sejauh mana alat pengukur untuk mengukur apa yang diukur. (Sugiono,2019) tinggi rendahnya validitas instrument menunjukkan sejauh mana data terkumpul tidak menyimpang dari gambaran tentang variabel yang di teliti. Oleh karena itu suatu instrument dikatakan valid sebagai alat ukur jika r-hitung lebih besar dari r-tabel. Reliabilitas adalah indek yang menunjukkan sejauh mana suatu alat pengukur dapat dipercaya atau dapat diandalkan Oleh karena itu pengujian reabilitas alat ukur dimaksudkan untuk menunjukkan sejauh mana alat ukur dapat diandalkan atau dipercaya dengan menggunakan nilai alpha cronbach lebih besar dari 0,6 maka konstruk variabel dapat dikatakan baik Secara rinci hasil olah data untuk uji validitas dan reliabilitas disajikan pada Tabel 1

Tabel 1 Rekapitulasi Hasil Uji Validitas dan Reliabilitas Instrumen

\begin{tabular}{|c|c|c|c|c|c|}
\hline Variabel & Item & $\begin{array}{l}\text { Koefisien } \\
\text { korelasi }\end{array}$ & Keterangan & $\begin{array}{l}\text { Alpha } \\
\text { Cronbach }\end{array}$ & Keterangan \\
\hline \multirow{5}{*}{ Nilai Satya } & $\mathrm{X} 1.1$ & 0,936 & Valid & \multirow{5}{*}{0,930} & \multirow{5}{*}{ Reliabel } \\
\hline & $\mathrm{X} 1.2$ & 0,855 & Valid & & \\
\hline & $\mathrm{X} 1.3$ & 0,905 & Valid & & \\
\hline & X1.4 & 0,817 & Valid & & \\
\hline & X1.7 & 0,936 & Valid & & \\
\hline \multirow{5}{*}{$\begin{array}{l}\text { Pengendalian } \\
\text { Internal }\end{array}$} & $\mathrm{X} 2.1$ & 0,969 & Valid & \multirow{5}{*}{0,938} & \multirow{5}{*}{ Reliabel } \\
\hline & $\mathrm{X} 2.2$ & 0,901 & Valid & & \\
\hline & $\mathrm{X} 2.3$ & 0,846 & Valid & & \\
\hline & $\mathrm{X} 2.4$ & 0,827 & Valid & & \\
\hline & $\mathrm{X} 2.5$ & 0,958 & Valid & & \\
\hline \multirow{5}{*}{$\begin{array}{l}\text { Kecurangan } \\
\text { Akuntansi }\end{array}$} & Y1 & 0,726 & Valid & \multirow{5}{*}{0,784} & \multirow{5}{*}{ Reliabel } \\
\hline & $\mathrm{Y} 2$ & 0,842 & Valid & & \\
\hline & Y3 & 0,830 & Valid & & \\
\hline & Y4 & 0,610 & Valid & & \\
\hline & Y5 & 0,710 & Valid & & \\
\hline
\end{tabular}


(Sumber: Data Primer diolah, 2021)

Berdasarkan Tabel 1 tersebut di atas, maka semua variabel memiliki korelasi di atas 0,138 dan nilai koefisien Alpha Cronbach berada diatas 0,6 sehingga instrumen tersebut adalah valid dan reliabel, sehingga layak dijadikan instrumen penelitian.

\section{B. Uji Asumsi Klasik}

\section{Uji Normalitas}

Uji statistik sederhana yang sering digunakan untuk menguji asumsi normalitas adalah dengan menggunakan uji normalitas dari Kolmogorov Smirnov. Metode pengujian normal tidaknya distribusi data dilakukan dengan melihat nilai signifikansi variabel, jika Asymp Sig. (2-tailed) lebih besar dari 5\%, maka menunjukkan distribusi data normal. Tabel dibawah ini menunjukkan hasil pengujian normalitas data dengan menggunakan alat bantu SPSS.

\section{Tabel 2 Uji Normalitas data Kolmogorov Smirnov}

\begin{tabular}{|ll|r|}
\hline & & Unstandardized Residual \\
\hline $\mathrm{N}$ & & 266 \\
Normal Parameters ${ }^{\mathrm{a}, \mathrm{b}}$ & Mean & .0000000 \\
& \multicolumn{1}{|c|}{ Std. Deviation } & 1.59654085 \\
Most Extreme & Absolute & .089 \\
Differences & Positive & .089 \\
& Negative & -.066 \\
Kolmogorov-Smirnov Z & .891 \\
Asymp. Sig. (2-tailed) & .406 \\
\hline
\end{tabular}

(Sumber : Data primer diolah, 2021)

Berdasarkan tabel diatas dapat diketahui bahwa nilai Asymp. Sig. (2tailed) sebesar 0,406 > dari $\alpha=0,05$. Jadi, dapat disimpulkan bahwa data tersebut telah memenuhi syarat normalitas.

\section{Uji Multikolinearitas}

Metode untuk mengetahui adanya multikolinearitas dalam model regresi adalah terlihat dari nilai tolerance dan variance inflation factor (VIF). Pada tabel 3 di bawah ini disajikan hasil perhitungan nilai tolerance dan VIF kurang dari angka 10 dan angka tolerance lebih dari 0,1 menggunakan program SPSS.

\section{Tabel 3 Hasil Uji Multikolinearitas}

\begin{tabular}{|c|c|c|}
\hline \multirow[t]{2}{*}{ Model } & \multicolumn{2}{|c|}{$\begin{array}{l}\text { Collinearity } \\
\text { Statistics }\end{array}$} \\
\hline & $\begin{array}{l}\text { Toleranc } \\
\text { e }\end{array}$ & VIF \\
\hline $\begin{array}{ll}1 & X \\
& X\end{array}$ & $\begin{array}{l}973 \\
, 971\end{array}$ & $\begin{array}{l}1,028 \\
1,030\end{array}$ \\
\hline
\end{tabular}

(Sumber: data Primer diolah, 2021)

Tabel 3 menunjukkan bahwa nilai tolerance pada variabel Konsep Satya 0,973, variabel Pengendalian internal i sebesar 0,971, dan variance inflation factor 
(VIF) variabel konsep satya sebesar 1,028 , variabel Pengendalian internal sebesar 1,030, maka dapat dikatakan tidak terjadi gejala multikolinearitas dalam model regresi.

\section{Uji Heteroskedastisitas}

Uji heteroskedastisitas menunjukkan bahwa variasi variabel tidak sama untuk semua pengamatan. Uji ini dapat dianalisis melalui uji Gleser dengan meregresikan nilai absolut residual sebagai variabel terikat dengan variabel bebas.Jika variabel bebas signifikan secara statistik mempengaruhi variabel terikat maka ada indikasi terjadi heteroskedastisitas (Sugiyono, 2019). Hasil uji heteroskedastisitas dapat dilihat pada Tabel 4

\section{Tabel 4 Uji Heteroskedasitas}

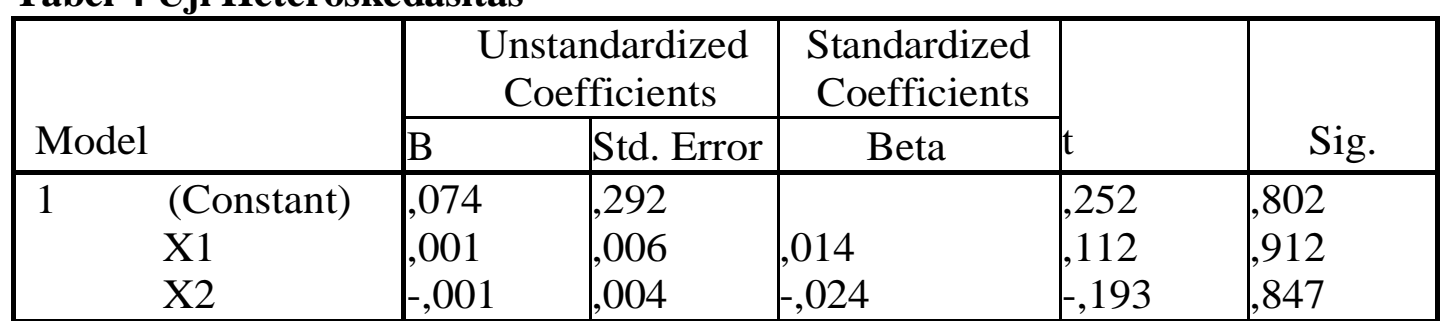

(Sumber: Data Primer diolah, 2021)

Berdasarkan Tabel 4, dapat diketahui bahwa nilai sig variabel Konsep Satya (X1) sebesar 0,912, variabel Pengendalian Internal (X2) sebesar 0,847 kedua variabel tersebut memiliki nilai sig > 0,05 yang artinya pada model regresi tidak terdapat heteroskedastisitas.

\section{Analisis Regresi Linier Berganda}

Model yang digunakan dalam menganalisis variabel-variabel yang mempengaruhi Kecenderungan Kecurangan Akuntansi adalah model analisis regresi linear berganda dengan bantuan program SPSS. Dalam model analisis regresi linear berganda yang menjadi variabel terikatnya adalah kecurangan akuntansi sedangkan yang menjadi variabel bebasnya adalah konsep satya, dan Pengendalian internal. Hasil regresi linier berganda ditunjukkan pada tabel 5

\section{Tabel 5. Hasil Analisis Regresi Berganda}

\begin{tabular}{|c|c|c|c|c|c|c|}
\hline \multirow{2}{*}{\multicolumn{2}{|c|}{ Model }} & \multicolumn{2}{|c|}{$\begin{array}{c}\text { Unstandardized } \\
\text { Coefficients }\end{array}$} & \multirow{2}{*}{$\begin{array}{c}\begin{array}{c}\text { Standardized } \\
\text { Coefficients }\end{array} \\
\text { Beta }\end{array}$} & \multirow[b]{2}{*}{$\mathrm{t}$} & \multirow[b]{2}{*}{ Sig. } \\
\hline & & $\mathrm{B}$ & Std. Error & & & \\
\hline & (Constant) & 1.396 & .974 & & 1.434 & .155 \\
\hline & $\mathrm{X} 1$ & -.799 & .031 & -.575 & -5.549 & .000 \\
\hline & $\mathrm{X} 2$ & -.174 & .027 & -.145 & -6.546 & .000 \\
\hline
\end{tabular}

Persamaan regresi $\mathrm{Y}=1,396-0,799 \mathrm{X}_{1}-0,174 \mathrm{X}_{2}$

Berdasarkan persamaan diatas maka dapat interprestasikan sebagai berikut :

1. Koefisien konstanta sebesar 1.399 dengan nilai positif ini dapat diartikan bahwa Y (kecenderungan kecurangan akuntansi) akan bernilai 1.397 jika pengendalian internal, kesesuaian kompensasi, dan ketaatan aturan akuntansi masing-masing bernilai 0 
2. Variabel Nilai satya dalam akuntansi memiliki koefisien regresi negatif sebesar 0,799. Nilai koefisien regresi negatif menunjukkan bahwa setiap kenaikan satu persen variabel Konsep satya, dengan asumsi variabel lain tetap maka akan menurunkan kecenderungan kecurangan akuntansi sebesar 0,799.

3. Variabel pengendalian internal memiliki koefisien regresi negatif sebesar -0,174. Nilai koefisien regresi negatif menunjukkan bahwa setiap kenaikan satu persen variabel kesesuaian kompensasi, dengan asumsi variabel lain tetap maka akan menurunkan kecenderungan kecurangan akuntansi sebesar 0,174

\section{Analisis Korelasi Berganda}

Analisis korelasi berganda digunakan untuk menguji tentang ada tidaknya hubungan antar variabel satu dengan yang lain secara serempak. Kemudian untuk mengetahui kuat lemahnya nilai korelasi akan diukur dengan menggunakan interpretasi nilai korelasi. Hasil uji korelasi berganda bisa dilihat pada tabel 6 .

\section{Tabel 6. Hasil Uji Korelasi Berganda}

\begin{tabular}{|l|l|l|l|}
\hline Model & $\mathrm{R}$ & R Square & Adjusted R Square \\
\hline 1 & $.977^{\mathrm{a}}$ & .955 & .953 \\
\hline
\end{tabular}

(Sumber, data primer diolah, 2021)

Berdasarkan tabel diatas diketahui bahwa hasil $\mathrm{R}$ diperoleh sebesar 0,977, apabila dihubungkan dengan interpretasi nilai korelasi menurut Sugiyono (2019) maka koefisien korelasi sebesar 0,977 terletak antara 0,80-1,000. Hal ini berarti terdapat hubungan yang sangat kuat antara variable Konsep Satya, Pengendalian internal Terhadap Kecenderungan Kecurangan Akuntansi di LPD Kabupaten Buleleng

Koefisien determinasi $\left(\mathrm{R}^{2}\right)$ pada intinya mengukur seberapa jauh kemampuan model dalam menerangkan variasi variabel independen. Nilai koefisien determinasi adalah antara nol dan satu (Ghozali 2013). Nilai koefisien determinasi $\left(\mathrm{R}^{2}\right)$ dapat dilihat pada tabel 6 Model Summary yang ada di atas. Dari tabel di atas terlihat tampilan output SPSS model summarybesarnya $R$ Square adalah 0,955. Maka besarnya determinasi adalah nilai $\left(\mathrm{R}^{2}\right)$ dikali $100 \%=0,955 \times 100 \%=95,5 \%$. Dengan demikian dapat dinyatakan bahwa perubahan Kecurangan Akuntansi (Y) di LPD Kabupaten Buleleng dikontribusi oleh Konsep Satya (X1), Pengendalian Internal (X2), sebesar $95,5 \%$ dan sisanya sebesar $4,5 \%$ dipengaruhi variabel lain yang tidak diteliti dalam penelitian ini.

\section{E. Uji Hipotesis}

Uji statistik t digunakan untuk mengetahui ada atau tidaknya pengaruh masingmasing variabel independen secara individual terhadap variabel dependen yang diuji pada tingkat signifikansi 0,05 . Jika nilai probability t lebih kecil dari 0,05 maka hipotesis diterima dan sebaliknya (Ghozali, 2013). Pada Tabel 5 diatas menunjukkan nilai hasil uji t pada konsep satya sebesar $0,000<0,05$, hal ini berarti menerima $\mathrm{H} 1$ sehingga dapat disimpulkan bahwa konsep satya berpengaruh signifikan terhadap kecenderungan kecurangan akuntansi. Pada nilai hasil uji t Pengendalian Internal sebesar $0,000<0,05$ yang berarti menerima $\mathrm{H} 2$ sehingga dapat disimpulkan bahwa 
pengendalian internal berpengaruh secara signifikan terhadap kecenderungan kecurangan akuntansi.

\section{Kesimpulan}

Penelitian ini bertujuan untuk mengetahui pengaruh pengendalian internal, kesesuaian kompensasi dan ketaatan aturan akuntansi terhadap kecenderungan kecurangan akuntansi. Responden pada penelitian ini berjumlah 266 orang yang bekerja di Lembaga perkreditan desa kabupaten buleleng. Berdasarkan data yang telah dikumpulkan dan diolah sehingga memperoleh hasil pengujian yang dilakukan terhadap perrnasalahan dengan menggunakan model regresi berganda, maka dapat diambil kesimpulan sebagai berikut:

1. Pengaruh Konsep Satya dalam Akuntansi terhadap Kecenderungan Kecurangan Akuntansi Pengujian pada hipotesis (H1) menunjukkan bahwa konsep satya akuntansi berpengaruh terhadap kecenderungan kecurangan akuntansi. Pada tabel 5 dapat dilihat hasil nilai uji statistik t variabel Konsep Satya dalam akuntansi sebesar 0,000 lebih kecil dari $\alpha=0,05$. Dengan demikian hipotesis H1 diterima sehingga dapat dikatakan bahwa Konsep Satya akuntansi berpengaruh terhadap kecenderungan kecurangan akuntansi. Konsep satya merupakan suati konsep agama hindu yang memberikan kesetiaan dan ketaan dalam melakukan pelaporan..

2. Pengendalian Internal berpengaruh signifikan terhadap kecenderungan kecurangan akuntansi dan menerima hipotesis satu $(\mathrm{H} 2)$. Hasil penelitian ini didukung oleh penelitian Thoyibatun (2009), dan Puspasari dan Suwardi (2012) bahwa pengendalian internal yang efektif akan menurunkan kecenderungan kecurangan akuntansi.

\section{References}

Ariyoga,I Nyoman. 2019. Nilai Pendidikan Agama Hindu Dalam Lontar Swargarohana Parwa. Satya Widya: Jurnal Studi Agama. Volume 2 Nomor 1

Artini, Ni Luh Eka Ari, I Made Pradana Adiputra, Nyoman Trisna Herawati. 2014. Pengaruh budaya etis organisasi dan efektivitas pengendalian internal terhadap kecenderungan kecurangan akuntansi pada satuan kerja perangkat daerah (skpd) kabupaten jembrana. e-Journal S1 Ak Universitas Pendidikan Ganesha. Volume 2 No.1

Bali Post. 2018. Dugaan Penggelapan Dana di LPD Bangkang Sudah Bertahun-tahun. https://www.balipost.com/news/2018/01/04/33381/Dugaan-Penggelapan-Dana-diLPD.html. Diakses pada tanggal 10 Juni 2020

Kompas.2020. Diduga Menyelewengkan Dana Nasabah, Ketua LPD Gerokgak Ditahan https://denpasar.kompas.com/read/2020/01/17/10281331/diduga-menyelewengkandana-nasabah-ketua-lpd-gerokgak-ditahan?page=all. Diakses Pada 10 juni 2020

Pasek, Gede Widiadnyana., Luh de Trisnawati. (2019). Konsep Parhyangan Dalam Mengurangi Kecurangan Akuntansi Pada Tekanan Situasional di LPD Kabupaten Buleleng. Jurnal Ilmiah Akuntnasi. Volume 2 No 1

Puspasari, N., \& Dewi, K. 2015. Pengaruh Penalaran Moral Aparat Pengawas Internal Pemerintah (APIP) dan Tekanan Situsional Terhadap Kecenderungan Melakukan Fraud 
Saat Mengaudit : Sebuah Studi Eksperimen. Prosiding Simposium Nasional Akuntansi XVII. Mataram.

Rizky, Muammar, Fauziah Aida Fitri. 2017. Pengaruh Keefektifan Pengendalian Internal, Ketaatan Aturan Akuntansi, Penegakan Hukum, Dan Perilaku Tidak Etis Terhadap Kecurangan Akuntansi. JIMEKA. Vol. 2, No. 2,

Sagara, Yusar, dan Fitri, Yani, Jalil. 2013. “Auditing”. Ciputat: UIN Jakarta Press UIN Syarif Hidayatullah Jakarta.

Sari, Ni Luh Putu Purnama., Gede, Adi, Yuniarta., dan Made, Pradana, Adiputra. 2015. "Pengaruh Efektifitas Sistem Pengendalian Internal, Ketaatan Aturan Akuntansi, Persepsi Kesesuaian Kompensasi, dan Implementasi Good Governance terhadap Kecenderungan Fraud (Studi Empiris pada SKPD di Kabupaten Tabanan". e-Journal S1 Ak, Vol: 3, No.1. Singaraja: Universitas Pendidikan Ganesha.

Shintadevi, Prekanida Farizqa, 2015. Pengaruh keefektifan pengendalian internal, ketaatan aturan akuntansi dan kesesuaian kompensasi terhadap kecenderungan kecurangan akuntansi dengan perilaku tidak etis sebagai variabel intervening. Jurnal Nominal. Volume IV no 2

Sugiyono, 2015, Metode Penelitian Kuantitatif Kualitatif dan R\&D, Alfabeta : Bandung

Udayani, Anak Agung K. Finty Udayani., Maria M. Ratna Sari. 2017. Pengaruh Pengendalian Internal Dan Moralitas Individu Pada Kecenderungan Kecurangan Akuntansi. E-Jurnal Akuntansi Universitas Udayana. Vol.18.3. Maret (201 